\title{
Effect of Levels of Nitrogen and Potassium on Growth and Yield of Rainfed Pearl millet (Pennisetum glaucum L.)
}

\author{
Buduri Bhanuchandar*, Marri Prasanthi and Joy Dawson
}

Department of Agronomy, Sam Higginbottom University of Agriculture, Technology and Sciences, Prayagraj, Uttar Pradesh, India

*Corresponding author

\section{A B S T R A C T}

Keywords

Pearl millet,

Nitrogen, Potassium and Yield

Article Info

Accepted:

15 October 2020

Available Online:

10 November 2020
The experiment comprising nine treatment combinations were laid out in randomized block design and replicated thrice. The treatment consisted combination of 3 levels of nitrogen viz. $75 \mathrm{~kg} / \mathrm{ha}, 60 \mathrm{~kg} / \mathrm{ha}$ and $45 \mathrm{~kg} / \mathrm{ha}$, and 3 levels of potassium viz. $20 \mathrm{~kg} / \mathrm{ha}, 30 \mathrm{~kg} / \mathrm{ha}$ and $40 \mathrm{~kg} / \mathrm{ha}$ along with Phosphorus at $40 \mathrm{~kg} / \mathrm{ha}$. The Yield parameters viz. Number of Heads/hill, Number of Grains/head, Grain yield, and maximum Gross return, Net return and $\mathrm{B}: \mathrm{C}$ ratio were recorded with the application of $75 \mathrm{~kg} / \mathrm{ha}$ Nitrogen $+40 \mathrm{~kg} / \mathrm{ha}$ Phosphorus $+40 \mathrm{~kg} / \mathrm{ha}$ Potassium.

\section{Introduction}

Pearl millet [Pennisetum glaucum (L.)] is the fifth most important cereal crop in the world after rice, wheat, maize and sorghum. Pearl millet is commonly known as bajra, cattail, spiked or bulrush millet. Pearl millet excels all other cereals due to its unique features $\mathrm{C}_{4}$ plant with high photosynthetic efficiency, high dry matter production capacity and is grown under the most adverse agro-climatic conditions where other crops like sorghum and maize fail to produce economic yields. It is widely grown rainfed cereal crop in the arid and semi- arid regions of Africa and southern Asia, and can be grown in areas where rainfall is not sufficient (200 to $600 \mathrm{~mm} / \mathrm{yr}$ ) for the cultivation of maize and sorghum. Pearl millet is rightly termed as "nutricereal" as it is a good source of energy, carbohydrate, protein, fat, ash, dietary fiber, iron and zinc. Its grain is more nutritious and the protein content is not only high but it is also of good quality. The grain contains $11-19 \%$ protein, $60-78 \%$ carbohydrates and $3.0-4.6 \%$ fat and also has good amount of phosphorous and iron. India is the largest producer of pearl millet, both in terms of area and production. In India, it is annually grown on 7.5 million ha area producing nearly 9.73 million tonnes of grains with productivity of $1305 \mathrm{~kg} / \mathrm{ha}$ during 201617 (Directorate of Millet Development, 2018). 


\section{Materials and Methods}

The experiment was conducted during the Kharif season 2019, at the Crop Research Farm, Department of Agronomy, SHUATS, Prayagraj. The soil of the experimental plot was sandy loam in texture, nearly neutral in soil reaction ( $\mathrm{pH} 7.3)$, low in organic carbon $(0.42 \%)$, available Nitrogen (219 kg/ha), available Phosphorus (13.50 kg/ha) and available Potassium (257 kg/ha). The experiment was laid out in randomized block design with three replications and nine treatments.

The treatment consisted combinations of 3 levels of nitrogen viz. $75 \mathrm{~kg} / \mathrm{ha}, 60 \mathrm{~kg} / \mathrm{ha}$ and $45 \mathrm{~kg} / \mathrm{ha}$ and 3 levels of potassium viz. 20 $\mathrm{kg} / \mathrm{ha}, 30 \mathrm{~kg} / \mathrm{ha}$ and $40 \mathrm{~kg} / \mathrm{ha}$.

The recommended dose of phosphorus at 40 $\mathrm{kg} / \mathrm{ha}$ was applied uniformly to all the treatments. The crop was sown with at a spacing of $45 \mathrm{~cm} \times 15 \mathrm{~cm}$ on $21^{\text {st }}$ July 2019 using a variety SHB-152 with a seed rate of 4 $\mathrm{kg} / \mathrm{ha}$.

\section{Results and Discussion}

The data pertaining to effect of nitrogen and potassium on different growth parameters, yield and yield attributes are presented and discussed here under

\section{Growth parameters}

The analysed data presented in Table 1 shown significant variations among all treatments. At 90 DAS significantly maximum plant dry weight $(54.11 \mathrm{~g})$ was recorded in $\left(\mathrm{T}_{7}\right) 75$ $\mathrm{kg} / \mathrm{ha}$ Nitrogen $+40 \mathrm{~kg} / \mathrm{ha}$ Phosphorus +40 $\mathrm{kg} / \mathrm{ha}$ Potassium, which was statistically at par with $\left(\mathrm{T}_{2}\right) 60 \mathrm{~kg} / \mathrm{ha}$ Nitrogen $+40 \mathrm{~kg} / \mathrm{ha}$ Phosphorus $+20 \mathrm{~kg} / \mathrm{ha}$ Potassium. Similar results of increased dry matter production with increased levels of nitrogen at all the growth stages of Pearl millet crop was reported by Kumar et al., (2004) and Reddy (2009). Better accumulation of dry matter in the form of shoot and root development has led to more uptake of potassium. Increased content and / or uptake of $\mathrm{K}$ due to increased nitrogen and potassium has been reported by Yadav et al., (2011).

Table.1 Effect of levels of Nitrogen and Potassium on dry weight, no. of heads/hill, no. of grains/head, grain yield and B:C ratio of Pearl millet

\begin{tabular}{|c|c|c|c|c|c|}
\hline TREATMENTS & $\begin{array}{c}\text { Dry weight } \\
\text { (g/plant) } \\
\text { at } 80 \text { DAS }\end{array}$ & $\begin{array}{l}\text { Heads/hill } \\
\text { (No.) }\end{array}$ & $\begin{array}{c}\text { Grains/head } \\
\text { (No.) }\end{array}$ & $\begin{array}{l}\text { Grain yield } \\
\quad(t / h a)\end{array}$ & $\begin{array}{l}\mathrm{B}: \mathrm{C} \\
\text { ratio }\end{array}$ \\
\hline 1. $75 \mathrm{~kg} / \mathrm{ha}$ Nitrogen $+20 \mathrm{~kg} / \mathrm{ha}$ Potassium & 43.18 & 2.56 & 1948.11 & 4.62 & 2.84 \\
\hline 2. $60 \mathrm{~kg} /$ ha Nitrogen $+20 \mathrm{~kg} /$ ha Potassium & 48.78 & 2.44 & 1910.11 & 4.22 & 2.52 \\
\hline 3. $45 \mathrm{~kg} / \mathrm{ha}$ Nitrogen $+20 \mathrm{~kg} /$ ha Potassium & 45.52 & 1.67 & 1897.33 & 3.72 & 2.11 \\
\hline 4. $75 \mathrm{~kg} / \mathrm{ha}$ Nitrogen $+30 \mathrm{~kg} /$ ha Potassium & 44.29 & 2.33 & 1971.89 & 4.79 & 2.87 \\
\hline $5.60 \mathrm{~kg} / \mathrm{ha}$ Nitrogen $+30 \mathrm{~kg} / \mathrm{ha}$ Potassium & 45.56 & 2.22 & 1859.78 & 4.53 & 2.76 \\
\hline $6.45 \mathrm{~kg} / \mathrm{ha}$ Nitrogen $+30 \mathrm{~kg} / \mathrm{ha}$ Potassium & 43.22 & 2.00 & 1877.78 & 4.02 & 2.34 \\
\hline 7. $75 \mathrm{~kg} / \mathrm{ha}$ Nitrogen $+40 \mathrm{~kg} / \mathrm{ha}$ Potassium & 49.66 & 2.67 & 1996.67 & 4.91 & 2.95 \\
\hline 8. $60 \mathrm{~kg} / \mathrm{ha}$ Nitrogen $+40 \mathrm{~kg} /$ ha Potassium & 46.33 & 2.22 & 1918.60 & 4.48 & 2.67 \\
\hline 9. $45 \mathrm{~kg} / \mathrm{ha}$ Nitrogen $+40 \mathrm{~kg} / \mathrm{ha}$ Potassium & 45.33 & 1.89 & 1866.67 & 3.93 & 2.24 \\
\hline F test & $\mathrm{S}$ & $\mathrm{S}$ & $\mathrm{S}$ & $\mathrm{S}$ & $\mathrm{S}$ \\
\hline $\mathrm{SEm}( \pm)$ & 1.38 & 0.15 & 21.18 & 0.25 & 0.14 \\
\hline $\mathrm{CD}(\mathrm{p}=0.05)$ & 4.15 & 0.44 & 63.49 & 0.53 & 0.41 \\
\hline
\end{tabular}




\section{Yield and yield attributes}

Significantly higher number of heads/hill (2.67) was recorded in $\left(T_{7}\right) 75 \mathrm{~kg} /$ ha Nitrogen + $40 \mathrm{~kg} / \mathrm{ha}$ Phosphorus + $40 \mathrm{~kg} / \mathrm{ha}$ Potassium, which was statistically at par with $\left(\mathrm{T}_{1}\right) 75$ $\mathrm{kg} / \mathrm{ha}$ Nitrogen $+40 \mathrm{~kg} / \mathrm{ha}$ Phosphorus +20 $\mathrm{kg} / \mathrm{ha}$ Potassium, $\left(\mathrm{T}_{2}\right) 60 \mathrm{~kg} / \mathrm{ha}$ Nitrogen +40 $\mathrm{kg} / \mathrm{ha}$ Phosphorus $+20 \mathrm{~kg} / \mathrm{ha}$ Potassium and ( $\left.\mathrm{T}_{4}\right) 75 \mathrm{~kg} / \mathrm{ha}$ Nitrogen $+40 \mathrm{~kg} / \mathrm{ha}$ Phosphorus + $30 \mathrm{~kg} / \mathrm{ha}$ Potassium. Significantly higher number of grains/head (1996.67) was recorded in $\left(T_{7}\right) 75 \mathrm{~kg} / \mathrm{ha}$ Nitrogen $+40 \mathrm{~kg} / \mathrm{ha}$ Phosphorus $+40 \mathrm{~kg} / \mathrm{ha}$ Potassium, which was statistically at par with $\left(\mathrm{T}_{1}\right) 75 \mathrm{~kg} / \mathrm{ha}$ Nitrogen + $40 \mathrm{~kg} / \mathrm{ha}$ Phosphorus + $20 \mathrm{~kg} / \mathrm{ha}$ Potassium and $\left(\mathrm{T}_{4}\right) 75 \mathrm{~kg} / \mathrm{ha}$ Nitrogen $+40 \mathrm{~kg} / \mathrm{ha}$ Phosphorus $+30 \mathrm{~kg} / \mathrm{ha}$ Potassium. Application of potassium improved the number of grains per head which might be due to the favourable effects of potassium on nutrient uptake, photosynthetic activity, improving its mobilization reported by Yadav et al., (2011). Significantly superior grain yield (4.19 t/ha) was recorded in $\left(\mathrm{T}_{7}\right) 75 \mathrm{~kg} / \mathrm{ha}$ Nitrogen $+40 \mathrm{~kg} / \mathrm{ha}$ Phosphorus $+40 \mathrm{~kg} / \mathrm{ha}$ Potassium, which was statistically at par with $\left(\mathrm{T}_{1}\right) 75 \mathrm{~kg} / \mathrm{ha}$ Nitrogen $+40 \mathrm{~kg} / \mathrm{ha}$ Phosphorus + $20 \mathrm{~kg} / \mathrm{ha}$ Potassium, $\left(\mathrm{T}_{4}\right) 75 \mathrm{~kg} / \mathrm{ha}$ Nitrogen $+40 \mathrm{~kg} / \mathrm{ha}$ Phosphorus + $30 \mathrm{~kg} / \mathrm{ha}$ Potassium, $\left(\mathrm{T}_{5}\right) 60 \mathrm{~kg} / \mathrm{ha}$ Nitrogen $+40 \mathrm{~kg} / \mathrm{ha}$ Phosphorus $+30 \mathrm{~kg} / \mathrm{ha}$ Potassium and $\left(\mathrm{T}_{8}\right) 60$ $\mathrm{kg} / \mathrm{ha}$ Nitrogen $+40 \mathrm{~kg} / \mathrm{ha}$ Phosphorus +40 $\mathrm{kg} / \mathrm{ha}$ Potassium. Increased grain yield due to varying levels of nutrients have also been reported by Munirathnam and Gautam, 2002 (90 kg N), Yadav and Yadav, 2004 (30 kg K), Guggari and Kalaghatagi, (2005) (60 kg N + $40 \mathrm{~kg} \mathrm{P})$, Singh et al., $2010 \quad(120 \mathrm{~kg}$ $\mathrm{N})$.Nitrogen application increases the activity of cytokinins in plant which leads to the increased cell-division and elongation. Nitrogen is a component of porphyrins of chloroplasts and hence, increased nitrogen fertilization increased the growth and yield of crop due to increased photosynthates production. Varied responses in straw yield due to varied levels of nutrients have also been reported by Munirathnam and Gautam, 2002 (90 kg N), Yadav and Yadav, 2004 (30 $\mathrm{kg} \mathrm{K})$, Yadav et al., 2011 (60 kg K), Jadav et al., $2011(120 \mathrm{~kg} \mathrm{~N})$, Reddy et al., 2016 (100 $\mathrm{kg} \mathrm{N}$ ).

\section{Economics}

Economic viability of crop management is the foremost criteria in transforming new investigations to farmers' field. The results pertaining to the cost: benefit analysis of the crop as influenced by nitrogen and potassium levels indicated that application of $\left(\mathrm{T}_{7}\right) 75$ $\mathrm{kg} / \mathrm{ha}$ Nitrogen $+40 \mathrm{~kg} / \mathrm{ha}$ Phosphorus +40 $\mathrm{kg} / \mathrm{ha}$ Potassium recorded the highest gross, net returns and $\mathrm{B}: \mathrm{C}$ ratio (2.95). The highest net return was obtained by application of nitrogen and potassium fertilization may have been due to the supply of their nutrients which synchronized with the peak period of nitrogen and potassium requirement that had produced higher yield by Reddy et al., (2016).

In conclusion on the basis of one season experiment, application of $75 \mathrm{~kg} / \mathrm{ha}$ Nitrogen + $40 \mathrm{~kg} / \mathrm{ha}$ Phosphorus + $40 \mathrm{~kg} / \mathrm{ha}$ Potassium is more productive and economically effective under rainfed conditions than the remaining treatment combinations.

\section{References}

Guggari, A.K and Kalaghatagi, S.B. 2005. Effect of fertilizer and biofertilizer on pearl millet (Pennisetum glacum) and pigeon pea (Cajanus cajan) intercropping system under rainfed conditions. Indian Journal of Agronomy. 50(1): 24-26.

http://millets.dacfw.nic.in

Jadhav, R.P., Khafi, H.R and Raj, A.D. 2011. Effect of nitrogen and vermicompost on protein content and nutrient uptake 
in pearl millet. Agriculural Science Digest. 31(4): 319-321.

Kumar, S., Kadian, V.S and Singh, R.C. 2004. Response of pearl millet (Pennisetum glaucum L.) hybrids to row spacing and nitrogen application. Annals of Agricultural Research. 25(1): 68-70.

Munirathnam, P and Gautam, R.C. 2002. Response of promising pearl millet (Pennisetum glaucum) cultivars to levels and time of nitrogen application under rainfed conditions. Indian Journal of Agronomy. 47(1): 77-80.

Reddy, B. P. S., Madhuri, K.V., Venkaiah, K and Prathima, T. 2016. Effect of nitrogen and potassium on yield and quality of pearl millet (Pennisetum glaucum L.). International Journal of Agricultural Innovations and Research. 4(4): 2319-1473.

Singh, B., Rana, D. S., Joshi, U. N. and Dhaka, A. K. 2012. Fodder yield and quality of pearl millet genotypes as influenced by nitrogen levels. Forage
Research. 38(1): 62-63.

Yadav, O.P. 2011. Project Coordinator's Review (2010-11) on Pearl Millet Research.

(http://www.aicpmip.res.in/pcr2011.pd f).

Yadav, R.L and Yadav, B.L. 2004. Effect of soil compaction and potassium fertilization on yield and water expense efficiency of pearl millet in loamy sand soil. Journal of the Indian Society of Soil Science. 52(2): 192-193.

Yadav, S.S., Abha Tikkoo, Sulthan Singh and Bikram Singh 2011. Potassium fertilization in cluster bean-mustard and pearl millet-mustard cropping systems. Journal of the Indian Society of Soil Science. 59(2): 164-168.

Yakadri, $M$ and Reddy, A.P.K. 2009. Productivity of pearl millet (Pennisetum glaucum L.) as influenced by planting pattern and nitrogen levels during summer. Journal of Research ANGRAU. 37(1\&2): 34-37.

\section{How to cite this article:}

Buduri Bhanuchandar, Marri Prasanthi and Joy Dawson. 2020. Effect of Levels of Nitrogen and Potassium on Growth and Yield of Rainfed Pearl millet (Pennisetum glaucum L.). Int.J.Curr.Microbiol.App.Sci. 9(11): 2194-2197. doi: https://doi.org/10.20546/ijcmas.2020.911.261 